\title{
A Study on Drudgery of Farm Women in Agricultural Activities in Udaipur District of Rajasthan, India
}

\author{
Shanabanu H. Malek ${ }^{1}$, S.S. Sisodia ${ }^{1}$ and Vikas Kumar ${ }^{2 *}$ \\ ${ }^{1}$ Department of Extension Education, MPUAT, Udaipur, India \\ ${ }^{2}$ Department of Extension Education, SKNAU, Jobner, India \\ *Corresponding author
}

\section{A B S T R A C T}

\begin{tabular}{|l|}
\hline Ke y w or d s \\
$\begin{array}{l}\text { Drudgery, farm } \\
\text { women, interview, } \\
\text { agricultural } \\
\text { activities, schedule }\end{array}$ \\
\hline Article Info \\
\hline $\begin{array}{l}\text { Accepted: } \\
\text { 12 May } 2019 \\
\text { Available Online: } \\
\text { 10 June } 2019\end{array}$ \\
\hline
\end{tabular}

\section{Keywords}

Drudgery, farm agricultural activities, schedule

Article Info

\section{Introduction}

Women constitute almost half of the work force engaged in agriculture. Rural women constitute the most important productive work force in the Indian economy. In rural India, the percentage of women who depend on agriculture for their livelihood is as high as 84.00 per cent. Agriculture in India contributes about 18.00 per cent GDP and is predominantly a female activity. The rural women participate in a broad range of agricultural activities such as production, processing, preservation and utilization of food. They play a key role in the entire food system starting from the selection of seed, sowing, manuring, weeding, drying, stacking storing and feeding the family from the harvested produce.

Women work longer and harder than men though they are paid less. They also work on more tasks than men. In spite of their contribution to farming, the women have largely remained invisible as active farmers. Most people have failed to recognize the work that the women's involvement in agriculture is enormous. 
Drudgery is generally conceived as physical and mental strain, fatigue, monotony and hardships experienced while doing to a job. Many agricultural operations and household activities performed by women involve a lot of physical strain, which create serious health problems in the long run. Since they are overburdened with so much work both at farm and home levels, there is a chance of neglecting their health.

Thus, the burden shared by women for the socio-economic development is twofold, one on the domestic front and the other on the economic front. It is certain, that if appropriate drudgery reducing farmstead implements are made available to the rural women, these would contribute to reduction in drudgery, increase capability, productivity and consequently thereby improved efficiency.

Keeping in this mind the present study carried out with specific objective "level of drudgery faced by farm women in agricultural activities".

\section{Materials and Methods}

The present study was conducted in Udaipur district of Rajasthan State. For this study, two tehsils namely Girwa and Vallabhnagar were purposively selected on the basis of the maximum female population in the district, from each tehsil 5 villages were selected on the basis of maximum female population so, total 10 villages from both tehsils were selected and from each tehsil 10 respondents were randomly selected.

Total 100 respondents selected from villages, they were interviewed, personally to collect the data with the help of pre structured interview schedule. Thereafter, data were tabulated, analysed and inferences were drawn in light of the objective.

\section{Results and Discussion}

\section{Drudgery faced by farm women in} agricultural activities

The activity wise drudgery involved in various farm operations faced by farm women were ascertained on the following point such as, average time spend on farm activities, frequency of performance of farm activity and degree of difficulty in doing farm activities. The results are presented in subsequent tables.

\section{Distribution of respondents according to level of drudgery in agricultural activities}

To get an overview of drudgery level, the respondents were divided into three groups viz., (i) low level of drudgery $(<55.54)$ (ii) medium level of drudgery (55.54 to 78.14) and high level of drudgery (>78.14). The groups were formulated on the basis of calculated mean and standard deviation of the adoption scores obtained by the respondents. The results are presented in the table 1. The data respect of level of drudgery involved in farm activities in Table 1 shows that, great majority of $(64.00 \%)$ respondents faced medium level of drudgery, followed by 13.00 per cent and 23.00 per cent of them who felt the work involved low and high level of drudgery respectively. Therefore, it could be inferred that majority of the respondents faced work of farm operations involved medium level of drudgery.

Analysis of Table 1 further reveals that majority $34(68.00 \%)$ respondents of Girwa tehsil and $30(60.00 \%)$ of Vallabhnagar tehsil faced medium level of drudgery. Likewise, 12 (24.00\%) respondents of Girwa tehsil and 11 $(22.00 \%)$ respondents of Vallabhnagar tehsil faced high level of drudgery. Whereas, 4 $(08.00 \%)$ and $9(18.00 \%)$ respondents of both Girwa and Vallabhnagar tehsil faced low level of drudgery respectively. 
Aspect wise drudgery of respondents regarding different agricultural activities

Analysis of Table 2 reveals that, 69.00 per cent farm women expressed activity of land preparation was difficult, followed by 27.00 per cent of farm women expressed activity of land preparation was most difficult and only 04.00 per cent of them expressed that it was natural. It shows that all the respondents carried out this operation seasonally and time spent on land preparation was 373.65 min. During land preparation drudgery faced by farm women was like back pain, knees pain, shoulder pain and muscles pain and muscles stretching.

Further, majority of the respondents $(73.00 \%)$ expressed sowing practices as most difficult, followed by 25.00 per cent respondents expressed this activity as difficult and only 02.00 per cent of farm women were expressed as easy activity. Time spent on sowing practices was $432.65 \mathrm{~min}$ and this operation carried out by 100.00 per cent respondents in each season. Drudgery faced by farm women during sowing practice was muscle stretch, shoulder pain and feet pain.

The third statement shows that 34.00 per cent of farm women expressed nutrient management activity as difficult followed by 33.00 per cent of respondents expressed this activity as most difficult and 17.00,15.00 and 01.00 per cent of respondents expressed as easy, natural and very easy respectively. Time spent on nutrient management activity was $320.95 \mathrm{~min}$ and this operation carried out by all selected respondents seasonally. Drudgery faced by farm women in nutrient management like pain in hand, neck and feet.

The fourth statement shows that majority $(62.00 \%)$ of farm women expressed crop protection activity as difficult followed by 29.00 per cent, 5.00 per cent, 03.00 per cent and 01.00 per cent respondents expressed as most difficult, natural, easy and very easy activities respectively. Time spent on this activity was $324.45 \mathrm{~min}$ and this operation carried out by 100.00 per cent respondents as fortnightly. Drudgery faced by farm women during crop protection was chemical reaction in hand, cracks in hand and feet and body pain.

Further fifth statement shows that majority (64.00\%) of respondents expressed irrigation activity as difficult followed by 20.00 per cent, 09.00 per cent and 07.00 per cent of respondents expressed as very easy, most difficult and easy activities respectively.

Time spent on irrigation activity was 216.15 min. and this activity carried out by 85.00 per cent respondents fortnightly followed by 15.00 per cent of respondents weekly. Drudgery faced during irrigation was backache, shoulder pain, stress in hand and feet or body pain.

Next look on sixth statement, i.e. intercultural operation, it was found that majority $(62.00 \%)$ of respondents expressed intercultural operation as difficult activity followed by 35.00 per cent and 03.00 per cent of respondents expressed as difficult and natural activities. Time spent on intercultural operation was $472.27 \mathrm{~min}$ and out of 100.00 per cent of respondents 80.00 per cent respondents performed this activity weekly, followed by 20.00 per cent as fortnightly. Drudgery faced by farm women in intercultural operation was increase heartbeat, stretch on hand and back, muscle pain and body pain.

Seventh statement shows that majority $(69.00 \%)$ of respondents expressed harvest and post-harvest activity as difficult activity followed by 31.00 per cent respondents expressed as most difficult activity. 
Table.2 Distribution of respondents according to drudgery faced by farm women in agricultural activities

\begin{tabular}{|c|c|c|c|c|c|c|c|c|c|c|c|c|c|}
\hline \multirow{3}{*}{$\begin{array}{l}\text { S. } \\
\text { N. }\end{array}$} & \multirow[t]{3}{*}{ Statements } & \multirow{3}{*}{$\begin{array}{l}\text { Average time } \\
\text { spent on farm } \\
\text { activities } \\
\text { (min) }\end{array}$} & \multirow{3}{*}{$\begin{array}{l}\text { Involvement } \\
\text { of } \\
\text { respondents }\end{array}$} & \multicolumn{5}{|c|}{ Frequency of performance of farm activity } & \multicolumn{5}{|c|}{ Degree of difficulty for doing farm activity } \\
\hline & & & & $\mathbf{S}$ & F & W & $\mathbf{A}$ & D & VE & $\mathbf{E}$ & $\mathbf{N}$ & D & MD \\
\hline & & & & 1 & 2 & 3 & 4 & 5 & 1 & 2 & 3 & 4 & 5 \\
\hline 1. & $\begin{array}{c}\text { Land } \\
\text { preparation }\end{array}$ & 373.65 & 100 & $\begin{array}{c}100 \\
(100.00)\end{array}$ & - & - & - & - & - & - & $\begin{array}{c}04 \\
(04.00)\end{array}$ & $\begin{array}{c}69 \\
(69.00)\end{array}$ & $\begin{array}{c}27 \\
(27.00)\end{array}$ \\
\hline 2. & $\begin{array}{l}\text { Sowing } \\
\text { practices }\end{array}$ & 432.65 & 100 & $\begin{array}{c}100 \\
(100.00)\end{array}$ & - & - & - & - & - & $\begin{array}{c}02 \\
(02.00)\end{array}$ & - & $\begin{array}{c}25 \\
(25.00)\end{array}$ & $\begin{array}{c}73 \\
(73.00)\end{array}$ \\
\hline 3. & $\begin{array}{c}\text { Nutrient } \\
\text { management }\end{array}$ & 320.95 & 100 & $\begin{array}{c}100 \\
(100.00)\end{array}$ & - & - & - & - & $\begin{array}{c}01 \\
(01.00)\end{array}$ & $\begin{array}{c}17 \\
(17.00)\end{array}$ & $\begin{array}{c}15 \\
(15.00)\end{array}$ & $\begin{array}{c}34 \\
(34.00)\end{array}$ & $\begin{array}{c}33 \\
(33.00)\end{array}$ \\
\hline 4. & Crop protection & 324.45 & 100 & - & $\begin{array}{c}100 \\
(100.00)\end{array}$ & - & - & - & $\begin{array}{c}01 \\
(01.00)\end{array}$ & $\begin{array}{c}03 \\
(03.00)\end{array}$ & $\begin{array}{c}05 \\
(05.00)\end{array}$ & $\begin{array}{c}62 \\
(62.00)\end{array}$ & $\begin{array}{c}29 \\
(29.00)\end{array}$ \\
\hline 5. & Irrigation & 216.15 & 100 & - & $\begin{array}{c}85 \\
(85.00)\end{array}$ & $\begin{array}{c}15 \\
(15.00)\end{array}$ & - & - & $\begin{array}{c}20 \\
(20.00)\end{array}$ & $\begin{array}{c}07 \\
(07.00)\end{array}$ & - & $\begin{array}{c}64 \\
(64.00)\end{array}$ & $\begin{array}{c}09 \\
(09.00)\end{array}$ \\
\hline 6. & $\begin{array}{c}\text { Intercultural } \\
\text { operation }\end{array}$ & 472.27 & 100 & - & $\begin{array}{c}20 \\
(20.00)\end{array}$ & $\begin{array}{c}80 \\
(80.00)\end{array}$ & - & - & - & - & $\begin{array}{c}03 \\
(03.00)\end{array}$ & $\begin{array}{c}62 \\
(62.00)\end{array}$ & $\begin{array}{c}35 \\
(35.00)\end{array}$ \\
\hline 7. & $\begin{array}{l}\text { Harvesting \& } \\
\text { post harvesting } \\
\text { activity }\end{array}$ & 478.44 & 100 & $\begin{array}{c}100 \\
(100.00)\end{array}$ & - & - & - & - & - & - & - & $\begin{array}{c}69 \\
(69.00)\end{array}$ & $\begin{array}{c}31 \\
(31.00)\end{array}$ \\
\hline 8. & Marketing & 264.25 & 100 & $\begin{array}{c}100 \\
(100.00)\end{array}$ & - & - & - & - & - & $\begin{array}{c}01 \\
(01.00)\end{array}$ & $\begin{array}{c}03 \\
(03.00)\end{array}$ & $\begin{array}{c}75 \\
(75.00)\end{array}$ & $\begin{array}{c}21 \\
(21.00)\end{array}$ \\
\hline 9. & Livestock & 312.83 & 100 & - & - & - & - & $\begin{array}{c}100 \\
(100.00)\end{array}$ & $\begin{array}{c}11 \\
(11.00)\end{array}$ & $\begin{array}{c}17 \\
(17.00)\end{array}$ & $\begin{array}{c}14 \\
(14.00)\end{array}$ & $\begin{array}{c}43 \\
(43.00)\end{array}$ & $\begin{array}{c}15 \\
(15.00)\end{array}$ \\
\hline 10. & Poultry & 81.25 & 05 & - & - & - & - & $\begin{array}{c}05 \\
(100.00)\end{array}$ & $\begin{array}{c}1 \\
(20.00)\end{array}$ & $\begin{array}{c}4 \\
(80.00)\end{array}$ & - & - & - \\
\hline 11. & Goatry & 228.8 & 06 & - & - & - & - & $\begin{array}{c}06 \\
(100.00)\end{array}$ & $\begin{array}{c}1 \\
(16.66)\end{array}$ & $\begin{array}{c}3 \\
(50.00)\end{array}$ & $\begin{array}{c}1 \\
(16.66)\end{array}$ & $\begin{array}{c}1 \\
(16.66)\end{array}$ & - \\
\hline
\end{tabular}


Table.1 Distribution of respondents on the basis of level of drudgery in agricultural activities

\begin{tabular}{|c|l|c|c|c|c|c|c|}
\hline S. No & Level of Drudgery & \multicolumn{1}{|c|}{ Tehsil Girwa } & \multicolumn{4}{|c|}{ Tehsil Vallabhnagar } & \multicolumn{2}{c|}{ Total } \\
\cline { 3 - 8 } & & $\mathrm{f}$ & $\%$ & $\mathrm{f}$ & $\%$ & $\mathrm{f}$ & $\%$ \\
\hline $\mathbf{1}$ & Low $(<55.54)$ & 04 & 08.00 & 09 & 18.00 & 13 & 13.00 \\
\hline $\mathbf{2}$ & Medium $(55.54$ to 78.14$)$ & 34 & 68.00 & 30 & 60.00 & 64 & 64.00 \\
\hline $\mathbf{3}$ & High $(>78.14)$ & 12 & 24.00 & 11 & 22.00 & 23 & 23.00 \\
\hline & Total & 50 & 100.00 & 50 & 100.00 & 100 & 100.00 \\
\hline
\end{tabular}

$\mathrm{f}=$ frequency, $\%=$ per cent

Table.3 Comparison of drudgery of farm women of Girwa and Vallabhnagar tehsil regarding different agricultural activities.

\begin{tabular}{|c|c|c|c|c|}
\hline S. No. & Category of sample & Mean & S.D. & ' $Z$ ' value \\
\hline 1. & $\begin{array}{c}\text { Respondents of Girwa } \\
\text { tehsil }\end{array}$ & 74.81 & 9.58 & $10.02^{* *}$ \\
\cline { 1 - 3 } $\mathbf{2 .}$ & $\begin{array}{c}\text { Respondents of } \\
\text { Vallabhnagar tehsil }\end{array}$ & 58.87 & 6.03 & \multirow{2}{*}{} \\
\hline
\end{tabular}

** Significance at $1 \%$ level of significance

Time spent on this activity was $478.44 \mathrm{~min}$ and all selected respondents carried out this activity seasonally. Drudgery faced by farm women during harvest and post-harvest activity was burning sensation, pain in hand, leg and muscle squeeze, increase blood pressure, red eyes due to dust particles, throat cluster, shoulder and neck pain or body pain.

Further looking on eighth statement, i.e. marketing of produce, it was found that 75.00 per cent respondents expressed as difficult activity followed by 21.00 per cent, 03.00 per cent and 01.00 per cent respondents expressed as most difficult, natural and easy activities respectively. Time spent on this activity was 264.25 min and all selected respondents carried out as seasonally. Drudgery faced by farm women during marketing was leg muscle stretching, waist pain, fatigue or body pain.

The ninth statement shows that majority (43.00 per cent) respondents expressed livestock activity as difficult activity, 17.00 per cent of respondents expressed as easy activity, 15.00 per cent, 14.00 and 11.00 per cent of respondents expressed as most difficult, natural and very easy activities respectively. Time spent on livestock activity was $312.83 \mathrm{~min}$. and 100.00 per cent of respondents carried out this daily activity. Drudgery faced by farm women during livestock operation was knee pain, hand muscles, pain in thumb, fatigue or body pain.

Regarding tenth statement, i.e. poultry, only 5 respondents had poultry. Out of 5 respondents it was found that only 4 respondents $(80.00 \%)$ expressed poultry activity as easy activity, followed by only 01 respondent $(20.00 \%)$ expressed as very easy activity respectively. Time spent on this activity was $81.25 \mathrm{~min}$ and given respondents were carried out as daily activity. Regarding poultry drudgery faced by respondents was body pain and fatigue.

Regarding last eleventh statement, i.e. goatry, only 6 respondents had poultry. out of 6 respondents it shows that only 03 respondents $(50.00 \%)$ expressed goatry activity as easy activity, followed by 03 respondents $(16.66 \%)$ each expressed poultry activity as difficult, easy and very easy activities respectively. Time 
spent on this activity was 228.8 min and given respondents were carried out as daily activity. Regarding goatry drudgery faced by respondents was pain in thumb, backache, strain, body pain, fatigue.

However, very less percentage of farm women did not perceived more drudgery in the activity namely poultry, goatry. Thus, it could be concluded that majority of farm women faced most drudgery in activities of land leveling, sowing practices, crop protection, intercultural operation, irrigation, harvest and post-harvest activities, marketing and livestock management.

Comparison between drudgery of farm women of both tehsil regarding different agricultural activities

To find out the significance of different between the farm women of selected tehsils with respect to drudgery faced by them, ' $Z$ ' test was applied. For this purpose, the following hypotheses was tested and results of which are presented in table 3.

$\mathrm{NH}_{01}$ : There is no significance difference between drudgery of farm women of selected tehsils regarding different agricultural activities.

$\mathrm{RH}_{01}$ : There is significance difference between drudgery of farm women of selected tehsils regarding different agricultural activities.

Table 3 shows that the calculated ' $Z$ ' value was found to be greater than its tabulated value at 1 per cent level of significance. Thus, the null hypotheses $\left(\mathrm{NH}_{01}\right)$ was rejected and alternate hypotheses $\left(\mathrm{NH}_{01}\right)$ accepted. It reveals that there was significant difference between the drudgery of farm women of two tehsils with respect to different agricultural activities.

Conclusion and suggestion are as follows:

It was concluded from the study that 64.00 per cent of the total respondents faced medium level of drudgery whereas, 23.00 and 13.00 per cent of total respondents faced high and low level of drudgery respectively. Majority of respondents faced drudgery in land preparation, sowing practices, crop protection, irrigation, intercultural operation and harvest \& postharvest activities and marketing.

\section{References}

Dudhal, H.S. 2017. Drudgery faced by farm women labourers in performing farm operations. M.Sc. (Agri.) Thesis (Unpub.), COA, Parbhani.

Girade, S. and Shmbharkar, Y. 2012. Profile of farm women and constraints faced by them in Participation of farm and allied activities. Indian journal of applies research. 12(1):69-71.

Thakare, M. 2013. Work satisfaction, and drudgery faced by women labourer in farm operations. M.Sc. (Agri.) Thesis (Unpub.), PDKV, Akola.

Tripathi, M.K., Sharma, J.P., Gautam, U.S., Parvez, R. and Arya, S. 2018. Participatory diagnosis of drudgery perceived by the women farmers: A micro level analysis. Journal of Community Mobilization and Sustainable Development 13(2):301-307.

Wankhede, P.P., Mankar, D.M., Kale, N.M., and Shambharkar, Y.B. 2015. Drudgery perceived by women labourers in farm operations. Indian Research Journal of Extension Education. 15 (3): 85-90.

\section{How to cite this article:}

Shanabanu H. Malek, S. S. Sisodia and Vikas Kumar. 2019. A Study on Drudgery of Farm Women in Agricultural Activities in Udaipur District of Rajasthan, India. Int.J.Curr.Microbiol.App.Sci. 8(06): 1584-1589. doi: https://doi.org/10.20546/ijcmas.2019.806.190 